that is going to destroy those cosmic rays." No matter what happens with the more speculative search for antimatter, the AMS should produce a definitive map of the cosmic-ray sky, helping to build a kind of astronomy that doesn't depend on light.

\section{LOOKING FOR COSMIC CURVEBALLS}

The toroidal magnet at the heart of the Alpha Magnetic Spectrometer bends the path of charged, high-speed particles, helping researchers to identify them.

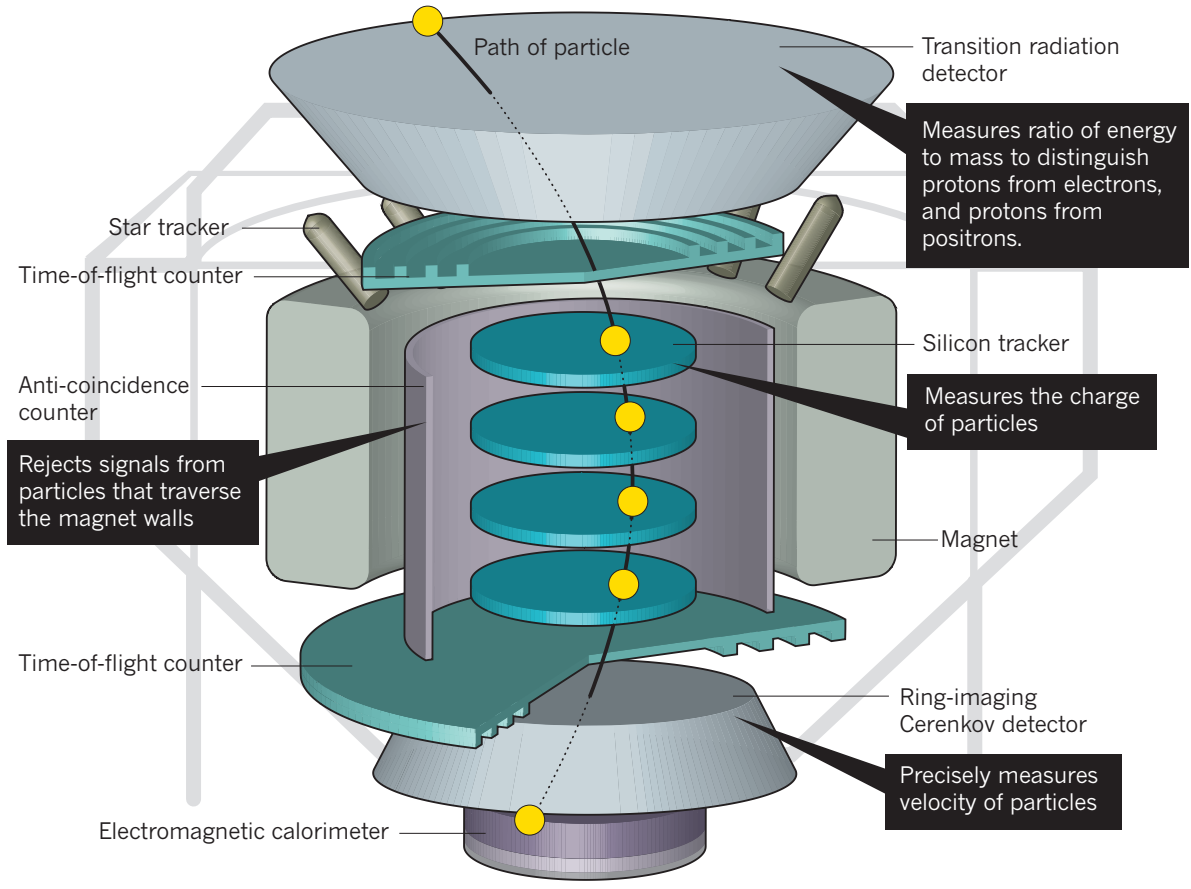

Some will turn out to be heavy atomic nuclei, and any made from antimatter will reveal themselves by bending in the opposite direction from their matter counterparts (see 'Looking for cosmic curveballs').

By counting positrons - antimatter electrons - the AMS could also chase a tentative signal of dark matter, the so-far-undetected stuff that is thought to account for much of the mass of the Universe. In 2009, researchers with the Russian-Italian Payload for Antimatter Matter Exploration and Light-nuclei Astrophysics, flying on a Russian satellite, published evidence of an excess of positrons in the space environment surrounding Earth (O. Adriani et al. Nature 458, 607-609; 2009). One potential source is the annihilation of dark-matter particles in the halo that envelops the Galaxy.

Another speculative quest is to follow up on hints of 'strange' matter, a hypothetical substance, perhaps found in some collapsed stars, that contains strange quarks along with the up and down quarks in ordinary nuclei. NASA's AMS programme manager, Mark Sistilli, says that hints of strange matter were seen in a pilot flight of the AMS aboard the shuttle in 1998, but that the results were too tentative to publish.

Thanks to its status as an exploration mission, the AMS did not need to go through the peer review that NASA would normally require of a science mission. But Sistilli emphasizes that it earned flying colours from committees convened by the energy department, which is supplying $\$ 50$ million of the funding. Now their confidence will be put to the test.

\title{
China unveils its space station
}

\author{
Plans for modest outpost solidify 'go it alone' approach.
}

\section{BY DAVID CYRANOSKI}

$\mathrm{T}$ he International Space Station (ISS) is just one space-shuttle flight away from completion, but the construction boom in low-Earth orbit looks set to continue for at least another decade. Last week, China offered the most revealing glimpse yet of its plans to deploy its own station by 2020. The project seems to be overcoming delays and internal resistance and is emerging as a key part of the nation's fledgling human space-flight programme. At a press briefing in Beijing, officials with the China Manned Space Engineering Office even announced a contest to name the station, a public-relations gesture more characteristic of space programmes in the United States, Europe and Japan.

China first said it would build a space station in 1992. But the need for a manned outpost "has been continually contested by Chinese space professionals who, like their counterparts in the United States, question the scientific utility and expense of human space flight", says Gregory Kulacki, China project manager at the Union of Concerned Scientists, headquartered in Cambridge, Massachusetts. "That battle is effectively over now, however, and the funds for the space station seem to have been allocated, which is why more concrete details are finally beginning to emerge."

Significantly smaller in mass than the ISS and Russia's Mir space station (see 'Rooms with a view'), which was deorbited in 2001, the station will consist of an 18.1-metre-long core module and two 14.4-metre experimental modules, plus a manned spaceship and a cargo craft. The three-person station will host scientific experiments, but Kulacki says it also shares the broader goals of China's human space programme, including boosting national pride and China's international standing.

The space-station project will unfold in a series of planned launches over the next ten years. Last Friday, official state media confirmed that the Tiangong 1 and Shenzhou 8 unmanned space modules will attempt a docking in orbit later this year, a manoeuvre that will be crucial for assembling a station in orbit. If that goes well, two manned Shenzhou craft will dock with Tiangong 1 in 2012. China will then move on to proving its space laboratory capabilities, launching Tiangong 2 and Tiangong 3 , which are designed for 20-day and 40-day missions, respectively, over the next 3 years. Finally, it will launch the modules that make up the station. 
Observers describe the programme as slow, systematic and cautious. According to the Chinese media, engineers have made more than 170 technical modifications to China's Long March rocket in preparation for the next series of launches. "As China is now really venturing into terra incognita with this stage of its manned space programme, the unknowns and risks are greater," says Eric Hagt, director of the China programme at the Center for Defense Information in Washington DC.

Hagt says that the station's small size is partly the result of advances in miniaturization since Mir and the ISS were designed and partly because China "needs to be economical and has stressed that all along. China has studiously avoided the impression that it is in a race, particularly with the United States."

China has said that its space technology will be compatible with that used in the ISS so that modules from other countries could dock with its station, and it promises that its facility will be able to host experiments from non-Chinese researchers. But the US Congress, fearing industrial espionage, has long opposed any role for China in the ISS. As a result, the Chinese space programme has had no alternative but to "go it alone", says Joan Johnson-Freese, an expert on national security and on China at the US Naval War College in Newport, Rhode Island.

Last week's announcement came just two weeks after the passage of a 2011 US federal spending bill that explicitly prohibits NASA from collaborating with China.

\section{ROOMS WITH A VIEW}

Space stations past, present and future.

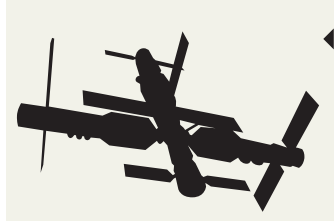

$\checkmark$ CHINESE SPACE STATION

Core-module length: $18.1 \mathrm{~m}$ Mass: 60 tonnes Crew: $\mathbf{3}$ (projected)

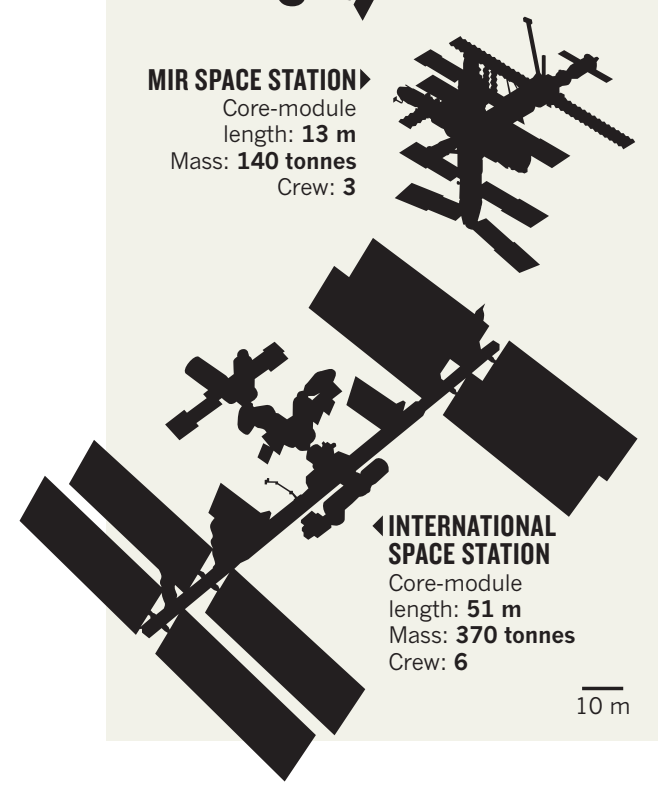

\title{
US stem-cell funding ban overturned
}

\author{
Appeals court decision bodes well for continued NIH \\ support of controversial research.
}

\section{BY MEREDITH WADMAN}

$\mathrm{U}$ S scientists working with human embryonic stem cells found reason for optimism - if not quite full-blown celebration - last week, after a high-ranking court overturned an injunction barring the National Institutes of Health (NIH) from funding their research. The ruling, handed down by the US Court of Appeals for the District of Columbia Circuit, significantly lowers the chances that opponents of the research will ultimately succeed in cutting off federal funding through the courts.

The field was thrown into disarray last August, when a lower court imposed the preliminary injunction while considering whether to permanently bar the government from funding the research (see Nature 467, $12-13 ; 2010)$. The action sent researchers supported by the NIH scrambling to suspend experiments and freeze cell lines, and forced the agency to halt peer review of new grant applications and approvals of new cell lines.

Seventeen days later, the appeals court placed a hold on the injunction while it considered the validity of the lower court's action. That restored the status of NIH funding, but left its long-term viability in doubt. This has been eased by the 29 April ruling, in which the appeals court legally formalizes its earlier decision to block the injunction.

It is, however, still possible that Judge Royce Lamberth of the US District Court for the District of Columbia, who issued the original injunction, will ultimately decide in favour of James Sherley and Theresa Deisher, the plaintiffs in the case. Deisher and Sherley, who both study adult stem cells, contend that NIH funding for research on human embryonic stem cells is illegal because it violates the DickeyWicker Amendment, a law that prohibits federal funding for research in which embryos are destroyed or discarded. But it will be difficult now for Lamberth to contravene the finding of the higher court that Dickey-Wicker does not ban NIH funding of research involving human embryonic stem cells, so long as they are not derived using federal funds. The threejudge panel of the appeals court concluded, by a two-to-one majority, that the weakness of the plaintiffs' central argument means they are unlikely to prevail when the case is heard on its merits - a key legal standard for granting a preliminary injunction.

The two judges wrote: "the NIH seems reasonably to have concluded that, although Dickey-Wicker bars funding for the destructive act of deriving an ESC [embryonic stem cell] from an embryo, it does not prohibit funding a research project in which an ESC will be used."

The plaintiffs' failure to meet another legal standard for winning the preliminary injunction - demonstrating that the harm they would suffer without it outweighs the harm caused to government-funded researchers if it is granted - clinched the court's decision.

NIH director Francis Collins pronounced himself "delighted and relieved" by the decision. "This is a momentous day - not only for science, but for the hopes of thousands of patients and their families who are relying on $\mathrm{NIH}$-funded scientists to pursue life-saving discoveries and therapies that could come from stem cell research."

Others tempered their optimism with caution. "Although this is great news and an important decision in favour of the patients and researchers who support stem-cell research, we have a long way to go before this is finally resolved," says Tony Mazzaschi, senior director, scientific affairs at the Association of American Medical Colleges in Washington DC.

The plaintiffs can still pursue a hearing by the full appeals court or the US Supreme Court, although the higher courts rarely grant such hearings.

Samuel Casey, a lawyer on the team representing Sherley and Deisher, says that lawyers for the plaintiffs will meet soon to decide their next steps. "We continue to strongly believe we will ultimately prevail in this case," he adds.

But researchers working with human embryonic stem cells hope the threat to their field is abating. "There's been a feeling of excitement tempered by sighs of relief," says George Daley of the Harvard-affiliated Children's Hospital Boston in Massachusetts. On Friday, Daley's e-mail inbox was flooded by messages from colleagues with subject lines such as "yay!" and "good news". Although nothing about the dayto-day work of his lab had changed, Daley says, "emotionally" the atmosphere is different. "We have been waiting for this for a long time." - 